\title{
TALEMPONG PACIK DALAM KEHIDUPAN MASYARAKAT NAGARI BUNGO TANJUNG: STUDI TENTANG POLA DAN BENTUK PEWARISAN
}

\author{
Ahmad Fauzan Yusman ${ }^{*}$, Indrayuda ${ }^{*}$ \\ Program Studi Pendidikan Ilmu Pengetahuan Sosial Konsentrasi Pendidikan Seni dan Budaya \\ Program Pascasarjana \\ Universitas Negeri Padang \\ Jl. Prof. Dr. Hamta, Air Tawar Padang, Kel. Air Tawar Barat, Kec. Padang Utara, Kota Padang, Kode Pos 25171 \\ Sumatera Barat. Indonesia \\ Email: fauzan2401@gmail.com
}

\begin{abstract}
Abstrak
Artikel ini menganalisis pola dan bentuk pewarisan serta menjelaskan kesenian talempong pacik di Nagari Bungo Tanjuang. Penelitian ini merupakan penelitian kualitatif dengan menggunakan metode deskriptif. Instrumen penelitian ini adalah peneliti sendiri dan dilengkapi dengan media audio visual serta pedoman wawancara dan observasi. Data dikumpulkan melalui wawancara, observasi dan kajian pustaka. Analisis data dilakukan dengan cara mengoleksi, menseleksi, menyajikan dan menguji data serta menyimpulkan. Hasil penelitian menunjukan bahwa, pewarisan dilakukan dengan tiga tipe, yaitu dengan pola pewarisan vertical transmission (pewarisan tegak) kepada anak, pewarisan kepada kemenakan dalam hubungan kekerabatan, pola pewarisan horizontal trasnmission (pewarisan datar) kepada orang yang sebaya dan pola pewarisan diagonal transmission (pewarisan miring) kepada murid diluar hubungan kekerabatan. Proses pembelajaran masih menggunakan oral dan demonstrasi, dimana guru akan mempraktekan cara bermain terlebih dahulu dan akan dicobakan secara langsung kepada murid.
\end{abstract}

Kata Kunci: talempong pacik, pewarisan, pola, bentuk.

\begin{abstract}
This article analyzes the pattern and inheritance form which explain the existence of talempong pacik art in Nagari Bungo Tanjuang. This study belongs to qualitative research with descriptive method. The main instrument in this research is the researcher himself and equipped by audio visual media and guided interview and observation. Data are gathered by using interview, observation and literature review. Data analysis was done by collecting, selecting, presenting, testing and concluding the data. The result of the research showed that inheritance is carried out in three types; first, the vertical transmission inheritance method (upright inheritance) which is inheritance to children and inheritance to nephew/niece or in kinship; second, horizontal transmission inheritance method (flat inheritance) to coeval people; third, diagonal transmission (oblique inheritance) to other people or to students outside the kinship. In teaching and learning process, oral and demonstration are still used where the teacher practice the way to play it first then followed by the student directly.
\end{abstract}

Keywords: talempong pacik, inheritance, pattern, form.

\section{PENDAHULUAN}

Kebudayaan nasional sebagai perwujudan dari Undang-undang Dasar Negara Republik Indonesia tahun 1945 Bab XIII pasal 32 tentang Pendidikan dan Kebudayaan dalam upaya memajukan kebudayaan nasional di tengah peradaban dunia dan menjamin kebebasan memelihara nilai budaya yang terdiri dari berbagai kebudayaan daerah di seluruh Indonesia. Salah satu contohnya adalah kebudayaan daerah Minangkabau, yang menjadi salah satu sub-kultur Indonesia yang berada di Provinsi Sumatera Barat.

Berdasarkan obserbasi awal yang peneliti lakukan, peneliti mengamati perkembangan dan pertumbuhan aktivitas talempong pacik di Kanagarian Bungo Tanjuang Kecamatan Batipuh, Kabupaten Tanah Datar. Di mana, kesenian talempong saat ini masih menjadi warisan budaya bagi masyarakat lokal. Kesenian Talempong pacik merupakan kesenian tradisional masyarakat setempat yang diterima dan diwarisi secara turun-temurun oleh masyarakat setempat dari generasi sebelumnya, dan saat ini diteruskan kepada generasi muda yang ada dinagari Bungo Tanjuang. Keberadaan talempong pacik tersebut memberikan petunjuk bahwa kanagarian Bungo Tanjuang memiliki kesenian tradisional yang sampai sekarang masih ada digunakan dalam masyarakat dan tetap dipertahankan kelestariannya. 


\section{KAJIAN TEORI}

Koentjaraningrat (1983:25) mengatakan bahwa kebudayaan adalah warisan sosial yang komplek meliputi dari keseluruhan pengetahuan, kepercayaan, kesenian, hukum, moral, kebiasaan dan lain-lain kecakapan dan kebiasaan yang diperoleh manusia sebagai anggota masyarakat. Budaya juga merupakan aturan dan batasan yang dibuat masyarakat untuk masyarakat itu sendiri.

Sebagai bagian dari unsur kebudayaan, kesenian yang masih tetap ada di Minangkabau. Kesenian ini lahir dalam budaya daerah Minangkabau yang menyebar ke seluruh pelosok daerah dengan ciri-ciri khas yang berbeda dan tercipta serta berkembang menurut aktivitas masyarakat itu sendiri. Dari aktivitas masyarakat itu, maka timbulah sifat kreatif dalam penggunaan musik itu sendiri, termasuk dalam hal ini penggunaan talempong pacik.

Telempong pacik merupakan alat musik sejenis bonang (Jawa), reong (Bali), atau totobuang (Bali) yang terbuat dari logam perunggu atau besi yang dimainkan secara satuan, baik ditempat maupun sambil berjalan (Soeharto, 1978:152). Talempong pacik sebagai musik tradisional Minangkabau, sampai saat sekarang masih tetap bertahan dibeberapa tempat. Dalam kata lain, masih dominan jika dibandingkan dengan beberapa kesenian tradisional yang lain. Namun akhirakhir ini talempong pacik dirasakan seakan-akan kurang mempunyai daya tarik lagi oleh beberapa generasi muda. Hal ini lah yang menjadi fokus dan tantangan para seniman di daerah agar kesenian ini tetap bertahan dan punah. Beberapa daerah di Sumatera Barat yang memiliki kesenian talempong yang tidak asing lagi antara lain adalah: Talempong Koto Anau (Kab. Solok), Talempong Padang Magek (Kab. Tanah Datar), Talempong Unggan (Kab. Sijunjung), Talempong Talang Maua (Kota Payakumbuh dan Kab. Limapuluh Kota), Talempong Jao (Kab. Tanah datar), Talempong Kapak Lasuang (Kab. Padang Pariaman), Caklempong (Negeri Sembilan-Malaysia) dan lainlain. Dalam hal ini penulis tidak akan mengkaji mengenai talempong yang berkembang di Sumatera Barat secara keseluruhan berhubung dengan keterbatasan waktu, maka penulis hanya membicarakan mengenai kesenian palempong pacik yang ada di nagari Bungo Tanjuang Kecamatan Batipuh Kabupaten Tanah Datar.

\section{METODE PENELITIAN}

Jenis penelitian yang digunakan dalam penelitian ini adalah penelitian kualitatif dengan menggunakan metode deskriptif seperti dikemukakan oleh Moleong
(1989:2) menyatakan bahwa Penelitian kualitatif selali bersifat deskriptif, artinya data yang dianalisa dari hasil analisanya berbentuk diskriptif. Fenomena yang tidak berupa angka-angka atau koefisien tentang hubungan antara variabel data yang terkumpul berbentuk katakata atau gambaran.

Senada dengan itu, menurut Sudarwan (2002:51) penelitian kualitatif bersifat deskriptif, yaitu data yang terkumpul berbentuk kata - kata, gambar, bukan angka - angka. Kalaupun ada angka - angka hanya bersifat sebagai penunjang saja. Didukung oleh pernyataan Best (dalam Darmadi, 2014:184) yang menambahkan bahwa penelitian deskriptif dikatakan sebagai metode penelitian yang berusaha menggambarkan dan menginterprestasi objek sesuai dengan apa adanya, dalam hal ini jujur dalam menyampaikan informasi dan menterjemahkan informasi tersebut. Data yang diperoleh melalui transkip wawancara, catatan lapangan, dan foto-foto. Dengan demikian pada penelitian ini akan dideskripsikan tentang kesenian talempong pacik dalam kehidupan masyarakat Bungo Tanjuang, ditinjau dari sistem pewarisannya. Teknik pengumpulan data dilakukan dengan cara studi pustaka, observasi dan wawancara. Teknik analisis data dengan cara data yang telah terkumpul kemudian dipilah berdasarkan pertanyaan guna mendapatkan jawaban permasalahan.

\section{HASIL DAN PEMBAHASAN \\ 1.Hasil}

Pewarisan budaya (transmission of culture) yaitu proses mewariskan unsur-unsur budaya dari satu generasi ke generasi manusia atau masyarakat berikutnya melalui proses pembudayaan (proses belajar budaya) seperti yang diungkapkan oleh Indrayuda (2013:56). Sesuai dengan hakikat dan budaya sebagai pemilik bersama masyarakat maka unsur-unsur kebudayaan itu memasyarakat dalam individu-individu warga masyarakat dengan jalan diwariskan atau dibudayakan melalui proses belajar budaya. Proses pewarisan budaya dilakukan melalui proses enkulturasi (pembudayaan) dan proses sosialisasi (belajar atau mempelajari budaya).

Menurut Sepdwiko (2018:19), kesenian tradisional dalam hal ini talempong pacik dapat diturunkan dan diwarisi oleh masyarakat dari masa ke masa dengan dua sistem, yaitu sistem terbuka dan sistem tertutup. Ada istilah lain yaitu transmisi horizontal dan transmisi vertikal. Sistem terbuka dengan pola transmisi diagonal atau horizontal merupakan sistem pewarisan yang dilaksanakan untuk seluruh masyarakat yang tinggal di nagari, tanpa memandang suku dan kerabatnya, 


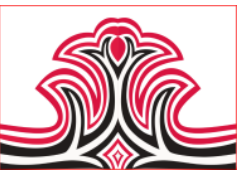

termasuk yang dilakukan oleh masyarakat nagari Bungo Tanjuang. Seperti yang diungkapkan oleh Tuti Artha dan Ahimsa (2004:54) bahwa warisan budaya dapat dibedakan menjadi tiga jenis, diantaranya adalah warisan yang merupakan milik pribadi, warisan yang merupakan milik kelompok kekerabatan dan warisan yang dianggap sebagai milik suatu komunitas atau masyarakat tertentu.

Dari ungkapan diatas ada warisan yang dimiliki secara pribadi dan ada yang warisan yang bisa diakses oleh umum. Begitu juga yang ditemui di nagari Bungo Tanjuang, bahwasanya ada talempong yang dimiliki oleh kaum dan dipelihara sebagai warisan, dan ada talempong yang digunakan sebagai sarana penyaluran gagasan bagi masyarakatnya. Talempong yang dimiliki kaum di nagari Bungo Tanjuang dijadikan harta warisan bagi kaumnya, sedangkan talempong yang dimiliki oleh kelompok ateh guguak sebetulnya diperuntukan untuk sarana kseenian dan bersifat terbuka.

Berkaitan dengan asal muasal talempong pacik secara umum, merujuk pada pepatah Minangkabau yang berbunyi, "Biriak-biriak turun ka samak, tibo di samak turun ka halaman. Dari niniak turun ka mamak, dari mamak turun kakamanakan" (Doris, 2016:3), yang artinya dari ninik (nenek moyang) turun ke mamak, dari mamak turun ke kemanakan, menjelaskan bahwa kesenian ini sebenarnya diwariskan dan diturunkan oleh generasi terdahulu kepada generasi selanjutnya, walau sampai saat ini sulit dibuktikan secara pasti mengenai asal muasal kesenian talempong pacik khususnya di nagari Bungo Tanjuang.

Dilihat dari bentuk secara umum, apa yang disebut talempong merujuk pada satu bentuk yang hampir sama dari ukuran serta bahan-bahan pembuatannya dengan alat musik gamelan di Jawa atau Bali. Salah satu persamaan yang bisa diambil dari alat musik serupa adalah alat musik ini termasuk kepada jenis alat musik idiophone (Banoe, 2003:191). Permainan talempong pacik menggunakan sistem interlocking yang dimainkan oleh beberapa orang. Permainan talempong pacik juga dikombinasikan dengan alat musik tradisi lainnya seperti gandang atau pupuik. Talempong ini nantinya berkembang menjadi talempong goyang yang mengkombinasikan tangga nada khas barat yaitu diatonik (Sastra, 2017:248).

\section{Pembahasan}

Berdasarkan hasil wawancara dengan Hajizar (wawancara 14 Juni 2019) bisa dikatakan bahwa talempong pacik di nagari Bungo Tanjuang merupakan
Gorga Jurnal Seni Rupa

Volume 08 Nomor 02 Juli-Desember 2019 p-ISSN: 2301-5942 | e-ISSN: 2580-2380

warisan sebagai milik komunitas. Artinya, siapa saja boleh mewarisi kesenian talempong pacik tersebut tanpa memandang hubungan kekerabatan/sapasukuan. Dalam hal ini talempong pacik di nagari Bungo Tanjuang bisa diwarisi oleh orang luar, baik dari luar kekerabatan, maupun luar nagari. Sedangkan sistem tertutup/transmisi vertikal adalah pewarisan yang dilakukan terkait secara langsung dalam kekerabatan dari pada masyarakat penganutnya. Selain hubungan kekerabatan pewarisan juga berdasarkan atas hubungan pertalian budi dan sapasukuan. Artinya siapa yang mewarisi dan menerima warisan tersebut, mereka harus mempunyai hubungan yang dekat dan erat.

Berkaitan dengan dua sistem diatas, pewarisan talempong pacik di nagari Bungo Tanjuang awalnya memang dilakukan dengan sistem tertutup dalam pola transmisi vertikal yang hanya dilakukan dalam satu kelompok sapasukuan, dari ayah ke anak atau dari mamak ke kemenakan. Namun pada perkembangannya, sistem tertutup dengan pola transmisi vertikal beriringan dengan sistem terbuka dengan pola transmisi diagonal atau horizontal. Walaupun, sampai saat sekarang pada kenyataannya kesenian ini masih dikelola oleh satu keleuarga saja secara turun temurun, tetapi terbuka untuk umum dalam mempelajari kesenian talempong pacik di Bungo Tanjuang ini.

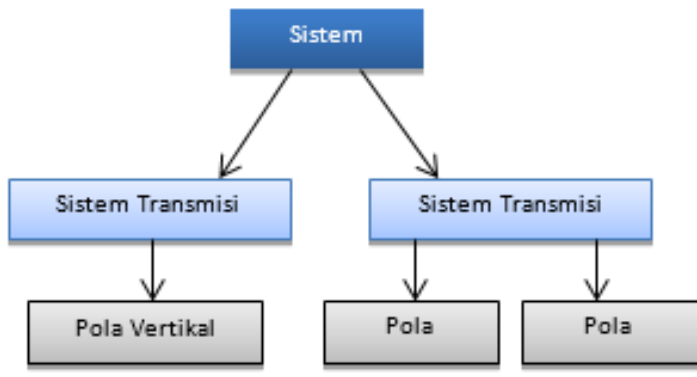

Gambar 1. Bagan Sistem Pewarisan yang Dilakukan Dalam Pewarisan Talempong Pacik di Nagari Bungo Tanjung. (Sumber: Ahmad Fauzan Yusman, 2019)

Pewarisan tidak hanya dilakukan dalam satu kaum koto saja, tetapi juga diajarkan kepada generasi muda yang ada di nagari Bungo Tanjuang secara umum. Menurut Bapak Hajizar, hal ini terjadi karena awalnya yang mempelajari talempong pacik, hanya satu kaum saja, mengingat tidak ada dari kaum lain yang berminat saat itu. Namun karena pemuda kaum koto mulai banyak yang merantau dan bekerja, sehingga diajaklah generasi muda yang ada di nagari Bungo Tanjuang bergabung dan mempelajari kesenian ini. Sejak itulah pewarisan tidak hanya dilakukan kepada anak kemenakan tetapi juga masyarakat umum. 
Dari beberapa hal di atas dikatehui bahwa sebuah kebudayaan selalu berkaitan dengan tiga aspek penting menurut Parsons (dalam Rohidi, 1994:516) mengenai pewarisan budaya, yaitu: pertama, kebudayaan merupakan sesuatu yang dialihkan dari satu generasi ke generasi lainnya, dalam hal ini kebudayaan dilihat sebagai sebuah warisan atau tradisi sosial. Seperti yang telah dilakukan oleh kelompok talempong pacik ateh guguak, pewaris menerima warisan kesenian talempong pacik dari tuo talempong terdahulu.

Pewaris dalam hal ini Hajizar dan Elizar menerima warisan dari senio-senior terdahulu dan meneruskan pewarisan kepada anak dan kemenakan mereka. Kedua, kebudayaan merupakan sesuatu yang dipelajari, dalam hal ini kebudayaan sesuatu yang dimiliki dari proses belajar. Selain pewarisan yang dilakukan melalui satu generasi kegenerasi selanjutnya, pihak lain yang berasal dari luar kemlompok, seperti luar kaum atau luar nagari, bisa diberi kesempatan dalam mempelajari talempong ini. Baik secara informal, seperti sanggra yang dipimpin oleh Sawir Dt. Sampono Marajo, tetapi juga dilakukan secara formal di sekolah dan dibantu oleh pemerintah daerah. Dan ketiga, kebudayaan itu dihayati dan dimiliki bersama oleh anggota masyarakat pendukungnya (Parsons dalam Cahyono, 2006:26). Dalam hal ini terjadi sebuah usaha pengalihan (oleh yang mewarisi) dan penerimaan (oleh pewaris) bertalian dengan substansi tertentu (kebudayaan) dengan tujuan agar dapat dijadikan sebagai suatu warisan sosial yang bermakna untuk pedoman hidup bagi masyarakat penganutnya.

\section{Pewarisan Talempong Pacik di Nagari Bungo Tanjung dengan Sistem Tertutup. \\ 1). Pola Pewarisan Tegak (Vertical Transmission)}

Berkaitan dengan sistem pewarisan, Cavalli-Sforza dan Feldman (dalam Berry, 1999:32) menyatakan bahwa terdapat beberapa jenis sistem pewarisan yaitu vertical transmission (pewarisan tegak), diagonal transmission (pewarisan miring) dan horizontal transmission (pewarisan datar). Pewarisan vertical transmission adalah sistem pewarisan yang berlangsung melalui mekanisme genetik yang diturunkan dari waktu ke waktu secara lintas generasi, yang melibatkan penurunan ciri-ciri kebudayaan dari orang tua kepada anak-cucu. Dalam pewarisan tegak, orang tua mewariskan nilai, keterampilan, keyakinan, motif budaya, dan sebagainya kepada anak-cucu mereka. Oleh karena itu pewarisan tegak disebut juga sebagai biological transmission yaitu sistem pewarisan yang memiliki sifat biologis.

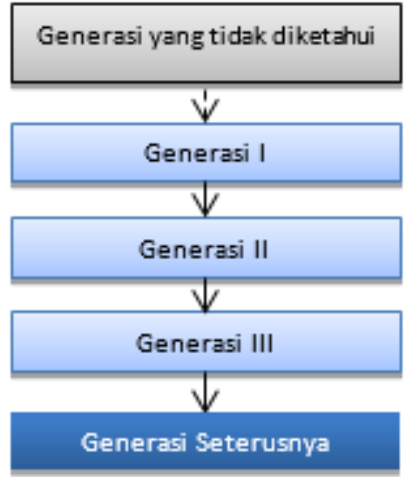

Gambar 2. Simulasi Pewarisan Vertikal. (Sumber: Ahmad Fauzan Yusman, 2019)

Jika merujuk kepada sistem pewarisan tertutup, pewarisan talempong pacik di nagari Bungo Tanjuang pada awalnya diwarisi dari satu generasi ke generasi tertentu. Kesenian talempong pacik ini dipelajari awalnya oleh beberapa keluarga saparuik (kumpulan beberapa keluarga kecil). Kebetulan keluarg tersebut memiliki suko koto. Keluarga kaum koto inilah yang mula-mula mempelajari kesenian ini. Sehingga kaum koto di nagari ini sangat identik dengan darah seniman. Tidak hanya kesenian talempong pacik, tetapi juga silek atau randai. Dari anak kemenakan inilah kesenian ini terus eksis dan dipertahankan sampai saat sekarang. Kaluarga Sawir Dt. Sampono Marajo hampir semuanya diajari bermain talempong pacik, hal ini dipelajari baik secara langsung, maupun hanya coba-coba. Setidaknya hal ini membuktikan salah satu sistem yang digunakan menggunakan sistem tertutup dengan pola vertikal.

\section{2). Bentuk Pewarisan dan Sistem Tertutup}

Menurut Murgiyanto (1983:31) bentuk seni terwujud berdasarkan akar prinsip yang sama dengan melandasi mewujudkannya dari tingkah laku dan kegiatan kehidupan manusia. Bentuk dalam dalam pewarisan bisa diterjemahkan sebagai hasil pola-pola yang sudah terbentuk sebelumnya. Sebuah karya seni agar bermakna dan dapat meyakinkan penghayatannya harus tumbuh dari pengalaman batin penciptaannya, pemain sampai masyarakat penganutnya sehingga berkembang sejalan dengan ide kebudayaan yang diwariskan.

Salah satu bentuk dari sistem pewarisan tertutup merujuk pada sistem kekerabatan. Sistem kekerabatan merupakan serangkaian aturan yang mengatur penggolongan orang-orang yang sekerabat (pertalian darah). Istilah kekerabatan digunakan untuk menunjukkan identitas para kerabat sehubungan dengan penggolongan kedudukan mereka dalam hubungan kekerabatan masing-masing. Maka hubungan sosial yang menyangkut kedudukan, hak, 
dan kewajiban antara seorang anak/kemenakan dan kerabat-kerabatnya dapat dilakukan dengan mudah dan tertib sesuai dengan aturan yang berlaku. Kelompok kekerabatan yang terkecil adalah sejumlah orang yang dapat dihubungkan satu sama lain melalui hubungan darah yang bersumber dari orang tua atau leluhur yang sama.

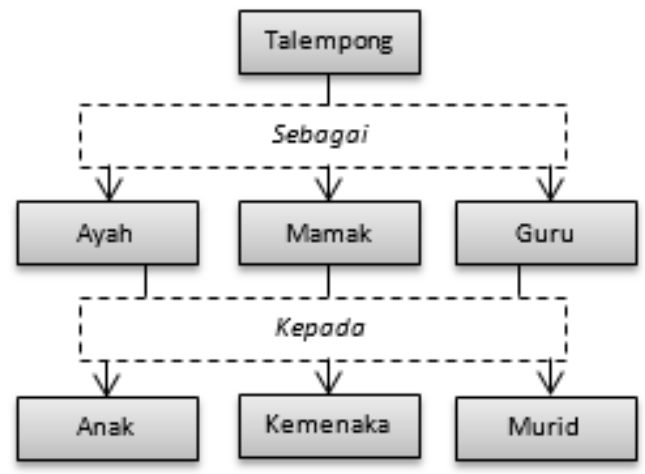

Gambar 3. Bentuk Hirarki Pewarisan yang Dilakukan di Nagari Bungo Tanjuang.

(Sumber: Ahmad Fauzan Yusman, 2019)

Daryusti (2011:61) menjelaskan bahwa setiap individu merupakan anggota dari beberapa kelompok masyarakat. Kelompok terkecil di Minangkabau menurut sistem garis ibu disebut kaum (suku). Setiap kaum/suku dipimpin oleh seorang kepala adat yang disebut dengan datuak atau Pangulu. Kaum merupakan kumpulan dari beberapa paruik (perut). Sebuah paruik terdiri dari nenek, ibuk, dan saudara-saudaranya, serta anak dari saudara perempuan ibu. Sebuah paruik dipimpin seorang tungganai yang diangkat berdasarkan musyawarah. Dalam sebuah keluarga di Minangkabau tentunya memiliki pola perilaku yang terbentuk dari aktivitas sehari-hari. Berkaitan dengan hubungan diatas, maka sebuah pewarisan kesenian, dapat melalui bentuk-bentuk diantaranya:

\section{(1). Pewarisan Ayah dan Anak}

Pewarisan ini dilakukan langsung oleh orang tua, dalam hal ini seorang ayah kepada anaknya, cucunya dan seterusnya, hal ini dapat diidentifikasi merupakan pola pewarisan tertutup (Nurasih, 2014:31). Menurut narasumber, Bapak Hajizar selaku pewaris kesenian talempong pacik, para tuo-tuo talempong biasanya mengajarkan kepada anaknya kemenakan dengan menggunakan sistem lisan (oral) dalam menyampaikan pesan/materi. Dalam hal ini pewaris secara langsung mengajarkan kepada anak/kemenakannya, sampai sekarangpun metode mengajarkan kesenian talempong pacik menggunakan sistem oral masih digunakan termasuk murid lainnya.

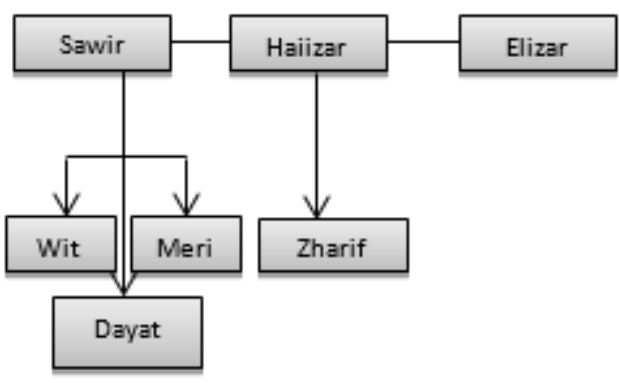

Gambar 4. Silsilah Pewarisan Talempong Pacik Bungo Tanjung dari Ayah ke Anak.

(Sumber: Ahmad Fauzan Yusman, 2019)

Untuk saat ini, dari informan Hajizar dan Elizar yang satu generasi dengan Sawir Dt. Sampono, mewariskan kesenian ini kepada masing-masing anak mereka. Dengan begitu pola ditemukanlan pola pewarisan tegak dari ayah ke anak dalam pewarisan talempong pacik di nagari Bungo Tanjuang.

\section{(2). Pewarisan dari Mamak ke Kemenakan}

Pada dasarnya masyarakat Minangkabau menganut sistem kekerabatan matrilineal atau matriakad, yaitu menarik garis keturunan dari pihak ibu yang berarti bahwa anak-anak merupakan keturunan dari ibu dan masuk ke dalam kekerabatan ibu dan mewarisi harta yang dimiliki ibunya. Mamak juga diartikan sebagai saudara laki-kali dari ibu. Jika sorang laki-laki di Minangkabau sudah menikah, maka dalam rumah kekerabatan istrinya ia dianggap sebagai orang sumando yang tidak memiliki kekuasaan penuh didalam rumah gadang istrinya.

Hubungan antara anak di Minangkabau tidak bergitu dekat dengan ayahnya, sebab seorang ayah bertugas mencari nafkah bagi keluarganya. Sebuah pepatah Minangkabau menyebutkan "Anak dipangku kamenakan dibimbiang" yang bermakna, anak dipangku kemenakan dibimbing. Hal ini menjelaskan bahwa laki-laki di Minangkabau yang berumah tangga tetapi laki-laki berfungsi untuk memelihara, menjaga anak kemenakannya sebagai menjadi tanggung jawabnya sebagai mamak dan menafkahi anak-anaknya sebagai seorang ayah.

Hubungan antara mamak dan kemenakan yang merupakan satu garis keturunan, berkaitan dengan pendidikan sampai kepada pengaturan hak atas warisan. Berbeda dengan sistem kekerabatan lainnya yang ada di Indonesia, kedudukan kemenakan memiliki posisi yang khusus dlam masyarakat Minangkabau yang menganut sistem matrilineal, sebab merekalah yang ditunjuk sebagai penerus generasi dalam kekerabatannya (kaum) (Edwar, 2010:22). Hal ini 


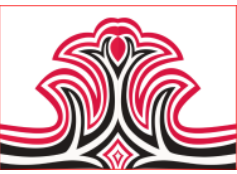

menjadikan peranan laki-laki atau suami anak-anaknya sangat kecil dibandingkan dengan peranan dan tanggung jawab seorang mamak pada kemenakannya.

Biasanya mamak akan mengomandoi tempo awal dalam permainan, selain itu juga tergantung pada pedoman bunyi nada talempong jantan yang muncul. Mamak akan menekankan hal yang terpenting disini, dalam memainkan talempong pacik, pemain harus mengetahui kapan seharusnya dan kapan saatnya nada talempong yang lain masuk (dimainkan) dan menyela. Setelah mereka bisa memainkan ketiga bunyi tersebut mereka disuruh memainkan secara bersama-samama. Demikian juga cara yang dilakukan kepada kemanakan dan muridnya.

\section{Pewarisan Talempong Pacik di Nagari Bungo Tanjuang dengan Sistem Terbuka.}

1). Pola Pewarisan Miring (Diagonal Transmission) Cavalli-Sforza dan Feldman (dalam Berry, 1999:32) juga menyatakan, selain sistem pewarisan vertical transmission (pewarisan tegak) terdapat juga pewarisan diagonal transmission (pewarisan miring) yaitu sistem pewarisan yang berlangsung melalui lembaga-lembaga pendidikan formal seperti sekolah dan perguruan tinggi atau pendidikan non formal seperti sanggar-sanggar. Diagonal transmission terjadi ketika seseorang belajar dari orang dewasa atau lembaga-lembaga (misalnya dalam pendidikan formal di sekolah) tanpa memandang apakah hal itu terjadi dalam budaya sendiri atau dari budaya lain. Sebagai salah satu dari hasil budaya, talempong merupakan salah satu objek yang dapat diwarisakan.

Seperti hasil wawancara dengan Elizani (wawancara 16 Juni 2019), salah satu upaya yang pernah dilakukan adalah dengan memperkenalkan kesenian ini dalam kegiatan formal disekolah dalam bentuk kegiatan ekstrakurikuler di MTsN 12 Tanah Datar. Pihak sekolah menjalin kerja sama dengan Dt. Sawir Sampono Marajo. Siswa-siswi yang berminat dikumpulkan dalam satu kelompok tidak memandang berasal dari suku, atau nagari apa, siswa yang berminant diajarkan langsung oleh Bapak Sawir. Pembelajaran yang berlangsung 1 sampai 1,5 jam ini juga masih diajarkan dengan metode oral dan modelling.

\section{2).Pola Pewarisan Mendatar (Horizonta Transmission)}

Menurut Cavalli-Sforza dan Feldman (dalam Berry, 1999:32) juga menyatakan, selain dua sistem pewarisan vertical transmission (pewarisan tegak) dan pewarisan diagonal transmission (pewarisan miring) juga terdapat
Gorga Jurnal Seni Rupa

Volume 08 Nomor 02 Juli-Desember 2019 p-ISSN: 2301-5942 | e-ISSN: 2580-2380

pewarisan horizontal transmission (pewarisan miring). Pewarisan ini terlihat pada aktivitas yang dilakukan oleh para seniman kesenian talempong pacik ateh guguak negari Bungo Tanjuang, dimana selain Sawir, Hajizar dan Elizar, ketiga seniman ini juga mengajarkan kepada reka-rekan sebayanya yang ada disekitar rumah mereka. Pola ini terkesan lebih santai sebab dilakukan dalam suasana santai, sampai menikmati suguhan makanan riangan dan berdiskusi ringan. Biasanya dahulu bapak Sawir, memanggil rekan-rekannya setelah beraktifitas disiang hari. Sambil bercengkrama Sawir mengajak rekan-rekannya itu berlatih, sehingga secara tidak langsung rekan-rekan tersebut juga bisa menguasai kesenian ini, dan ketika ada sebuah acara rekan-rekan tersebut bisa diajak dalam pertunjukan.

Pada kelompok ateh guguak ada beberapa generasi yang bisa dikatakan satu angkatan atau sebaya seperti Hole St. Pangulu yang satu generasi dengan Datuak Tapa, Kamin St. Bungsu dengan Nawan Sidi Sutan, dan Sawir Dt Sampono Marajo dengan Buyuang St. Mudo. Diantara pemusik diatas ada pemusik yang lebih ahli sehingga bisa memberikan pengarahan kepada yang lain. Disini dapat disimpulkan selain pewarisan miring dari guru ke murid juga memungkinkan pewarisan dengan segenerasi.

\section{3). Bentuk Pewarisan dengan Sistem Terbuka} (1). Pewarisan dari Tuo Talempong ke Murid di Sanggar

Sistem yang digunakan guru mengajarkan talempong pacik kepada muridnya dilakukan secara bertahap agar tidak kesulitan dalam mengingat bunyinya. Guru tidak mengajarkan satu lagu sampai selesai. Pada pertengahan lagu guru menyuruh muridnya untuk menyelesaikannya sampai habis. Setelah mereka menguasai satu buah lagu, baru murid dan guru bermain secara bersama-sama dengan menggunakan alat musik tambahan seperti pupuik, tamburin dan gandang/tambua. Teknik inilah yang paling sering digunakan guru talempong pacik dalam mengajarkan kepada anak, kemenakan dan murid-muridnya sampai saat sekarang ini.

\section{(2). Pewarisan dari Guru ke Murid di Sekolah- sekolah (formal)}

Berkaitan dengan itu sekolah memiliki peran penting sebagai media transfer pengetahuan dan informasi kepada siswa yang merupakan generasi penerus. Hal ini berbanding lurus dengan upaya pewarisan kesenian talempong pacik di nagari Bungo Tanjuang. Salah satu sekolah yang pernah mempelajari talempong pacik khas nagari Bungo Tanjuang ini adalah Madrasah 
Tsanawiyah Negeri (MTsN) 12 Kecamatan Batipuh Kabupaten Tanah Datar. Menurut narasumber lain yaitu Elizani, atau yang akrab dipanggil buk eli, yang merupakan bundo kanduang di nagari Bungo Tanjuang, bahwa pewarisan talempong pacik ini pernah diusahakannya bersama Sawir Dt. Sampono Marajo lewat ekstrakurikuler di MTsN 12 Tanah Datar. Beliau yang juga merupakan wakil kepala sekolah bidang kurikulum di Madrasah tersebut sempat membuat kelompok kesenian tradisional yang bertitik fokus kepada talempong pacik. Elizani sempat berkolaborasi dengan Sawir Dt. Sampono Marajo yang diundang sebagai pelatih. Namun karena keterbatasan waktu, Sawir Dt. Sampono Marajo tidak sempat melanjutkan kerja sama lagi. Setidaknya sudah ada usaha yang dilakukan oleh tuo talempong untuk bekerjasama dengan instansi formal seperti sekolah. Maka dapat disimpulkan bahwa sekolah salah satu media yang paling tepat untuk tempat pewarisan dalam hal ini kesenian talempong pacik secara efektif, terstruktur dan formal.

\section{KESIMPULA DAN SARAN}

\section{Kesimpulan}

Dalam falsafah Minangkabau dikatakan bahwa adaik basandi syarak, syarak basandi Kitabullah yang bermakna Adat bersendikan syarak (agama) dan syarak bersendikan kitab Allah yaitu Alquran. Hal inilah yang menjadi pedoman atau patokan dalam bertingkah laku, bersikap, berbicara, bergaul dan berpakaian, dan lainnya bagi masyarakat Minangkabau termasuk berkesenian. Talempong pacik merupakan salah satu kesenian musik tradisional Minangkabau yang juga terdapat di nagari Bungo Tanjuang Kecamatan Batipuh Kabupaten Tanah Datar. Dimana sampai saat sekarang ini masih tetap eksis dan tetap terjadi pewarisannya. Proses pewarisannya itu berlangsung dengan menggunakan sistem lisan (oral) dimana guru mentransfer ilmu secara langsung dan murid menggunakan daya ingat untuk dapat menerima pelajaran tersebut. Teknik yang digunakan adalah guru langsung mengajarkan dan murid mendengar dan melihat.

Dapat disimpulkan bahwa pewarisan kesenian talempong di nagari Bungo Tanjuang saat ini hanya terbatas pada sanggar yang dimiliki oleh Alm. Sawir Dt. Sampono Marajo (tokoh kesenian talempong di nagari Bungo Tanjuang) yang diteruskan oleh putra serta adik adiknya. Adapun secara formal disekolah yang ada di sekitar nagari bungo tanjuang mempelajari lagu (gua) talempong yang diketahui secara umum di seluruh Minangkabau, seperti gua cak dindin atau gua tari piriang khas nagari Bungo Tanjuang.

\section{Saran}

Talempong pacik sebagai kesenian rakyat yang telah turun-temurun sejak dulu perlu dilestarikan dan dikembangkan oleh semua pihak, untuk menghindari kepunakan yang akan merugikan kita sebagai pemiliknya. Selanjutnya, juga isarankan pada generasi muda saat ini disamping menyenangi kebudayaan baru yang berasal dari luar, namun jangan melupakan dan tetap mencintai, mempelajari dan membudayakan kebudayaaan bangsa sendiri salah satunya seperti melestarikan kesenian tradisional talempong pacik ini.

\section{DAFTAR RUJUKAN}

Ahimsa, P., \& Heddy, S. (2004). Warisan Budaya

Dalam "Jejak Masa Lalu: Sejuta Warisan

Budaya”. Arwan Tuti Artha. Yogyakarta: Kunci Ilmu.

Banoe, Pono. (2003). Kamus Musik. Yogyakarta: Kanisius.

Berry, John W. et al. (1999). Psikologi Lintas Budaya, Riset dan Aplikasi. (Terjemahan Edi Suhardono). Jakarta: Gramedia Pustaka Utama.

Cahyono, A. (2006). Pola Pewarisan Nilai-Nilai Kesenian Tayub (Inheritance Pattern of Tayub Values). Harmonia: Journal of Arts Research and Education, 7(1),

Darmadi, H. (2014). Metode Penelitian Pendidikan dan Sosial. Bandung: Penerbit Alfabeta.

Daryusti. (2011). Hegemoni Penghulu dalam Perspektif Budaya (Edisi Revisi). Yogyakarta: Cipta Media.

Doris, R. (2016). Kedudukan Putusan Kerapatan Adat Nagari (Kan) sebagai Alat Bukti Dalam Penyelesaian Perkara Pusako Tinggi pada Pengadilan Negeri Padang. Program Pascasarjana. Universitas Andalas. Padang.

Edwar, E. (2010). Pergeseran Tanggung Jawab Mamak Kepala Waris terhadap Anak Kemenakan pada Masyarakat Pariaman Perantauan menurut Hukum Adat Minangkabau Kota Jambi. Program Pascasarjana. Universitas Diponegoro. Semarang.

Hajizar, dkk. (1993). Talempong Tradisional di Nagari Pitalah dan Bunga Tanjung. Fakultas Seni Kerawitan. Akademi Seni Karawitan Indonesia Padang Panjang. Padang Panjang.

Indrayuda. (2013). Tari sebagai Budaya dan Pengetahuan. Padang: UNP Press.

Koentjaraningrat. (1983). Pengantar Ilmu Antropologi. Jakarta: PT Rineka Cipta.

Moleong, Lexy. P. (1989). Metode Penelitian Kualitatif. Bandung: CV Kemaja Karya.

Murgiyanto, S. (1983). Koreografi Pengetahuan Dasar Komposisi Tari. Jakarta: Departemen Pendidikan dan Kebudayaan. 
Nurasih, N. (2014). Proses Pewarisan Dalang Topeng

Cirebon. Makalangan, 1(01),

Rohidi, T. R. (1994). Pendekatan Sistem Sosial

Budaya dalam Pendidikan. Semarang: Semarang

Press.

Sastra, A. I., Fulzi, N., \& Anton, S. (2017).

Postcolonial Aesthetics: Talempong Kreasi and

Talempong Goyang in West Sumatra. Jurnal

Humaniora, 29(3), 245.

Sepdwiko, D. (2016). Hadirnya Musik Gong

Perunggu dalam Upacara Adat Kenduri Sko pada

Masyarakat Kerinci Provinsi Jambi. Jurnal

Sitakara, 1(1),

Soeharto, M. (1978). Kamus Musik Indonesia. Jakarta:

Gramedia.

Sudarwan, Danim. (2002). Menjadi Peneliti Kualitatif.

Bandung: Pustaka Setia. 